\title{
The health of a nation
}

\section{The Medical World of Early Modern France}

by Laurence Brockliss and Colin Jones

Oxford University Press: 1997. Pp. 960. £80,

$\$ 150$

\section{W.F.Bynum}

"They order, said I, this matter better in France", famously remarked the English clergyman and novelist Laurence Sterne as he set out from Dover to Calais on A Sentimental Journey (1767). He was referring to his dinner, but we can now judge whether the French ordered their medical care better as well.

The Medical World of Early Modern France is probably the fullest account ever written of a country's medical experience over several centuries. It is certainly the most sophisticated. Laurence Brockliss and Colin Jones have mined an incredible range of archival and printed sources during their 13-year project: manuscript case records and correspondence, matriculation registers and theses, the archives of hospitals and the minute-books of medical corporations, medical advice manuals and learned Latin tomes, diaries and memoirs, the records of court and parliament. The result is a big monograph in every sense: more than 800 pages of text, a bibliography of more than 60 pages and an index just as long.

More importantly, the volume has a clear thematic structure, so that the luxuriant details never lose their significance. Colourful anecdotes and witty asides carry the reader effortlessly along. Despite its magnitude, this is a book that invites reading from cover to cover.

For Brockliss and Jones, the "early modern" extended from the sixteenth century to the eve of the French Revolution. They divided their labours. Brockliss deals primarily with the more formal elements of the landscape - medical knowledge and education, the changing shape of medical theories, the faculties, colleges and institutions that formed the backbone of what the authors call the "corporative" structure of French medicine. Jones covers the more social dimensions of their subject demography and epidemics, the patient's experience of disease and death, and the medical penumbra of irregular healers, quacks and charlatans, midwives and folk remedies. They have successfully melded their individual writing styles, and the volume speaks with a unified, eloquent voice.

So did the French order their medical system better than their European neighbours? There were certainly differences, for the French developed a highly structured network of corporations during the six- teenth and seventeenth centuries, which encompassed physicians, surgeons and apothecaries, and was not confined to Paris and the other large cities. It was sanctioned by the state, where the dominant mercantilist economic philosophy gave its blessing to monopolies for those engaged in risky or useful enterprises. The number and power of these medical colleges, faculties and communities declined during the Enlightenment, as those that survived became more élitist but, ironically, less influential.

And French legislation from the late seventeenth century provided a formal framework for medical and surgical training and, by extension, licensing. Surviving records permit Brockliss and Jones to provide reasonable estimates of the number and distribution of physicians and surgeons during the period. By contrast, comparable national legislation in Britain was not passed until 1858.

These formal trappings of "professionalism" (cooperatism might be a more apt word) did not prevent the vigorous activities of drug pedlars and medical showmen, such as Désidério Descombes in the early seventeenth century or Jean Thomas (le Grand Thomas was his trade name) a century later. Descombes sold a secret remedy called orviétan for a range of routine maladies such as plague and rabies, while Thomas specialized in pulling teeth. The Pont Neuf in Paris was for a long time a gathering place for quacks and mountebanks plying their wares and services. The policing of such activities was generally spasmodic, and the antiquack literature of French physicians was as lively as that in England, where the medical marketplace was always much more open.

Nor did medical corporatism guarantee peace and harmony among regular practitioners. The medical faculties in Paris and Montpellier long regarded each other with suspicion sometimes bordering on outright hostility; physicians jealously guarded their right to be present at the examination of surgical students; and physicians and surgeons squabbled over which group was best able to deal with the lucrative business of venereal disease.

Despite these and many other examples of intra-occupational conflict, Brockliss and Jones do not conclude that healers in early modern France were simply cynical, self-serving vultures preying on a gullible public. Rather, they argue convincingly that Molière's trenchant critique of doctors in his plays was no more than caricature. For the most part, sick people trusted their medical attendants, and most doctors did

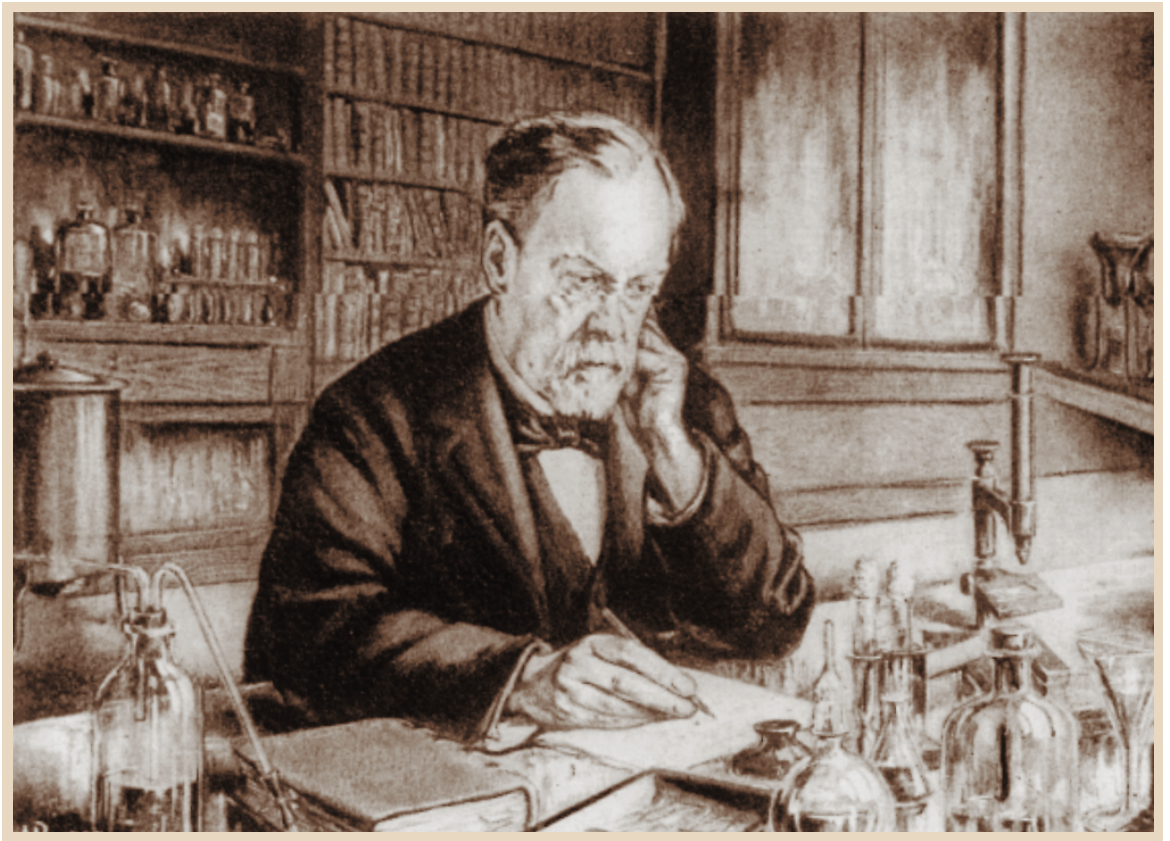

\section{France's famous scientific immortal}

This picture of Louis Pasteur seated in his laboratory appeared on an advertising card for the Urodonal Company in honour of the centenary of Pasteur's birth. It is reproduced in the paperback edition of The Private Science of Louis Pasteur by Gerald L.
Geison (Princeton University Press, \$16.95, $\mathfrak{E} 14.95)$. Drawing extensively on Pasteur's laboratory notebooks, made available only recently, the book was praised on its original publication by W. F. Bynum in Nature 375 , 25 (1995). 
the best they could. It was not just the doctors who would have seen poetic justice when Molière dropped dead on stage during the third performance of Le Malade Imaginaire. (Even hypochondriacs sicken and die sooner or later.)

As always, it seems, medical theories changed more regularly than medical practice. The authors dissect the nuances of Galenism, Paracelsianism, iatromechanism, vitalism and the other 'isms' that permeated medical thinking. They also describe minutely the bleeding and purging that were the mainstays of treatment for many diseases. In 1658 Louis XIV was repeatedly bled and purged during a fever (probably typhus) which almost killed him. Even his physician, Antoine Vallot, was happy, Ambroise Parélike (Je le pensay, Dieu le guarit), to attribute the outcome to providence. (The 20-yearold monarch lived for another 57 years.) Both doctors and patients approached their mutual encounters with a healthy dose of fatalism.

In 1720, five years after Louis' death, plague struck France for the last time. Brockliss and Jones analyse the epidemic in Marseilles and argue that it was a turningpoint for the country's doctors. Although the reasons why the plague was confined to Marseilles were more administrative than medical, the doctors received much of the credit. And they earned it: almost 22 per cent of the doctors sent to care for the plague victims in 1720 died. Traditional advice - medical and lay - about how to cope with plague was contained in the aphorism cito, longe, tarde (leave early, go far, come back late). By remaining at their posts, doctors had demonstrated their integrity, even courage.

There are many other facets to this wonderful book: vivid reconstructions of the contours of several medical practices; analysis of medical incomes; reflections on

\section{New in paperback}

\section{Radiogenic Isotope Geology}

by Alan P. Dickin

Cambridge University Press, £29.95, $\$ 44.95$

"Fills an important niche by providing an encyclopaedic, research-level review of the principles, methods and applications of radiogenic isotopes in geology... a notable contribution to the scientific literature on radiogenic isotope geology". Joel D. Blum, Nature 381, 126 (1996).

\section{An Interpretive Introduction to} Quantum Field Theory

\section{by Paul Teller}

Princeton University Press, \$16.95, £14.95

"This is a valuable book. Indeed, the specific interpretive proposals [Teller] makes could have an influence on hidden-variable theories... the development during the Enlightenment of preventive medicine, hospitals and surgery; shrewd insights on the changing shape of medical ethics and doctor-patient relationships. These are but a few examples. The volume is quite simply a stunning achievement, a monument to cooperation and humane scholarship.

W. F. Bynum is at the Wellcome Institute for the History of Medicine, 183 Euston Road, London NW1 2BE, UK.

\section{The higher idiocy}

\section{Yes, We Have No Neutrons: An Eye- opening Tour Through the Twists and Turns of Bad Science}

by A. K. Dewdney

Wiley: 1997. Pp. 180. £17.99, \$22.95

\section{Walter Gratzer}

"Anybody who goes to a psychiatrist ought to have his head examined," Sam Goldwyn sagely observed. Here at least was one central European (born Shmuel Gelbfisch) who was not in the grip of the prevailing fashion. The tide has since turned against Freud (not before time), and for Professor Dewdney in his pursuit of intellectual deviance he presents a soft target.

The subtitle of Dewdney's book rather begs the question of what anyway constitutes science. A definition is always elusive, and the term has in any case been stolen from us, for what greater oxymoron can one conceive of than 'political science'? No doubt we shall one day hear talk of literary science and perhaps even theological science; after all, we already have creation science. So today's jest becomes tomorrow's degree course. But Dewdney, who seems to base his own valuations entirely on the teachings of Karl Popper, might have recalled that the sage regarded psychoanalysis, which he loathed, as the

[The] book reflects a welcome trend toward a reassessment of the notions of meaning and visualization in contemporary science". Peter Holland, Nature 378, 454 (1995).

Resistance to New Technology: Nuclear Power, Information Technology and Biotechnology edited by Martin Bauer Cambridge University Press, $£ 24.95, \$ 39.95$ "Consists of papers presented at a conference at the Science Museum in London. Under the rubric of 'resistance', many different stories are told from many different perspectives. Some are stories of comparative diffusion; others of policies for regulating particular technologies; some of public attitudes to certain new technologies". David Edgerton, Nature 376, 653 (1995). antithesis of science. It is not bad science: it is not science at all.

Dewdney keeps clear, rather surprisingly, of the 'dismal science' of economics, which John Maynard Keynes, unlike a horde of his successors, regarded as unamenable to quantitative analysis. Nor, in the social and medical line, has Dewdney considered one of the most truly pernicious examples of spurious science - the frontal lobotomy operation, which for decades was inflicted indiscriminately on the vulnerable, most often without consent and with almost uniformly disastrous consequences. For this Egas Moniz, who invented the procedure, was rewarded with the 1949 Nobel Prize for Medicine.

Dewdney does deal effectively with the measurement and heritability of intelligence, and the racial undertones of that sinister subject. But his adherence to Popper, with frequent incantations about what is and what is not falsifiable, leads him to an extreme view of, for example, the search for extraterrestrial intelligence (SETI). In truth this is no more "bad science", as Dewdney defines it, than the study of cosmology or of evolution, where one has to make do without controls, and the principle of falsifiability scarcely helps. Dewdney, in common with many others, is entitled to regard SETI as a waste of public funds and certainly one of the more chancy ventures. But, Popper notwithstanding, an intelligent signal from the void would be sufficient to prove him wrong.

Dewdney lumps SETI with various failed initiatives, driven by manic ambition, greed or injured pride, such as the cold-fusion fiasco and the ill-starred Biosphere 2 project. But can one really compare neural networks with these sad failures? Dewdney does not assert that the many successes of this computational technique are all illusory, only, when one reads carefully, that it has been hyped far beyond its real value. That may be so, but by such a measure how much of recent cancer research could escape damnation (let alone gene therapy, say)? I would have chosen catastrophe theory as a better example in applied mathematics; this enjoyed a short-lived vogue a decade or so ago, with supposed solutions to half of all human predicaments. Among many other revelations that stick in the mind, it presented an astonished world with a rigorous proof that an aggressive dog would attack suddenly, rather than gradually.

Dewdney, who is a mathematician and who inherited the "Mathematical Recreations" column in Scientific American from Martin Gardner, is best on his home ground. He is especially clear on issues of probability (SETI) and statistical analysis (IQ tests). He writes in a wearingly populist style and is profligate with clichés; nor is he too fastidi- 